Article

\title{
Immunization against Hepatitis B Surface Antigen (HBsAg) in a Cohort of Nursing Students Two Decades after Vaccination: Surprising Feedback
}

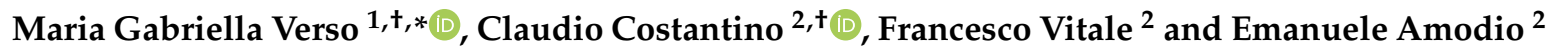 \\ 1 Department of Health Promotion Sciences, Maternal and Infantile Care, Internal Medicine and Medical \\ Specialties "G. D'Alessandro", Occupational Health Unit, University of Palermo, Piazza Marina, 61, \\ 90133 Palermo, PA, Italy \\ 2 Department of Health Promotion Sciences, Maternal and Infantile Care, Internal Medicine and Medical \\ Specialties "G. D'Alessandro", Section of Hygiene, University of Palermo, Piazza Marina, 61, \\ 90133 Palermo, PA, Italy; claudio.costantino01@unipa.it (C.C.); francesco.vitale@unipa.it (F.V.); \\ emanuele.amodio@unipa.it (E.A.) \\ * Correspondence: mariagabriella.verso@unipa.it; Tel.: +39-368-396-7350 \\ + These authors contributed equally to this work.
}

Received: 8 November 2019; Accepted: 17 December 2019; Published: 19 December 2019

\begin{abstract}
Health-care students can be exposed to biological risks during university training. The persistence of long-term immunogenicity against hepatitis B virus (HBV) was analyzed in a cohort of nursing students two decades after primary vaccination. A total of 520 students were enrolled at the University of Palermo and were evaluated for levels of anti-HBsAg antibodies. The students were examined during the first year of their Degree Course and were checked two years later. All students with anti-HBsAg $<10 \mathrm{mIU} / \mathrm{mL}$ during their first or third year were boosted within one month. The proportion of students that were vaccinated during adolescence showing anti-HBsAg $\geq 10 \mathrm{mIU} / \mathrm{mL}$ was higher than that observed in students who were vaccinated during infancy $(69 \%$ versus $31.7 \%$; $p$-value $<0.001$ ). Receiving $\mathrm{HBV}$ vaccination at adolescence was significantly associated with a fourfold increased possibility of having anti-HBsAg titers $\geq 10 \mathrm{mIU} / \mathrm{mL}$ (adj-OR $=4.21,95 \%$ CI: 2.43-7.30). Among the students who were checked at the third year and boosted after the first year $(n=279)$, those who were vaccinated during infancy showed a higher percentage of antibody titers $<10 \mathrm{mIU} / \mathrm{mL}$ ( $20.3 \%$ versus $8.7 \%$ among vaccinated during adolescence; $p<0.01)$. This study confirms that $\mathrm{HBV}$ vaccination at adolescence might determine a higher long-term persistence of anti-HBsAg titers $\geq 10 \mathrm{mIU} / \mathrm{mL}$ and that anti-HBV booster could increase levels of anti-HBsAg over a relatively short period, especially in subjects who were vaccinated during infancy.
\end{abstract}

Keywords: HBV infection; HBV vaccination; Anti-HBs titer; Healthcare students; work related biological risk

\section{Introduction}

The World Health Organization (WHO) estimates that about 59 million health care workers (HCWs) are exposed to multiple occupational hazards every day, the most common being the risk of exposure to infected patients and/or infectious materials, including body fluids, contaminated medical supplies and equipment, environmental surfaces, or air [1].

In particular, hepatitis B virus (HBV) represents the most transmissible blood-borne virus following percutaneous exposure among healthcare workers [2]. 
In Italy, according to the national law, healthcare students are considered workers and, therefore, if they are exposed to physical, chemical, biological, or psychological risks, they should be examined by an occupational health physician to evaluate the risks related to their practical activities [3].

Standard precautions, the adoption of enhanced percutaneous injury precautions, and HBV vaccination of HCWs have been demonstrated to consistently reduce the risk of occupational infections and prevent nosocomial transmission of the virus [4].

About $95 \%$ of the population who are vaccinated against HBV will develop an effective immune response, which can be confirmed by the evaluation of antiHBsAg antibodies (protective level $\geq 10 \mathrm{mIU} / \mathrm{mL}$ ) [5].

Some studies suggest that the acquired immunity persists for at least 10 years after vaccination with antibody levels $\geq 10 \mathrm{mIU} / \mathrm{mL}$, however probably not longer if vaccination was performed during the neonatal age [6,7].

In Italy, universal and compulsory HBV vaccination was introduced in 1991 with a two-cohort strategy [8]. In particular, since 1991, HBV vaccination was administered to infants and 12-year old adolescents on a national scale [8].

In Italy, among subjects who were vaccinated against HBV from 1991 to 2003, higher immunization levels were observed among those who were vaccinated during adolescence [9].

The 2017 to 2019 Italian National Vaccination Plan strongly recommends the active offer of HBV vaccination to all healthcare professionals [10].

Several researches conducted among students attending healthcare courses highlighted the importance of measuring the immunological response against HBV and of the need for a booster dose in subjects with not protective values, since they have to be considered at higher risk of acquiring HBV infection due to traineeships and/or internships in hospital units [11-16].

The main goal of this study was to evaluate persistence of long-term immunogenicity of anti-HBV vaccination and to identify possible predictive factors associated with a stronger immunological response to primary vaccination.

Moreover, a reassessment was carried out during the third year of the study course, two years after the first examination, and levels of antiHBsAg were analyzed and discussed for students that were boosted and those that were not.

\section{Materials and Methods}

From November 2015 to April 2019, a cohort of 520 students attending the nursing schools at the University of Palermo, Italy was evaluated for serum HBsAg, anti-HBs, and anti-HBc. Students were examined during their first and third academic years for evaluating occupational risks. The first-year examination was conducted in 2015/2016, whereas the third-year examination was conducted during 2018/2019.

A standardized medical record including socio-demographic factors (age, gender, country of origin), clinical information (relatives' diseases and personal remote and proximate pathologies), and previous HBV vaccination was filled-out for each student. Moreover, a medical examination and a blood withdrawal were performed for each student.

Students who were negative for HBsAg and anti-HBc, with titers of anti-HBs lower than 10 $\mathrm{mIU} / \mathrm{mL}$, were subsequently boosted and the titer was reassessed after one month.

According to Italian law, a written informed consent was obtained from all the subjects [17].

The study was approved by the Ethical Committee of the University Hospital "P. Giaccone" of Palermo (Protocol number 26/2016 of the 19th of October 2016).

All enrolled nursing students were previously vaccinated against HBV, they were HBsAg negative, and none of them received a vaccination booster before the enrollment.

Among 520 students who were enrolled at the occupational examination for their first year, 449 were further evaluated at a follow-up visit at the third year and 71 were considered lost at follow-up due to changing or dropping-out of the study course. 
The flow chart that is reported in Figure 1A,B describes the study population.
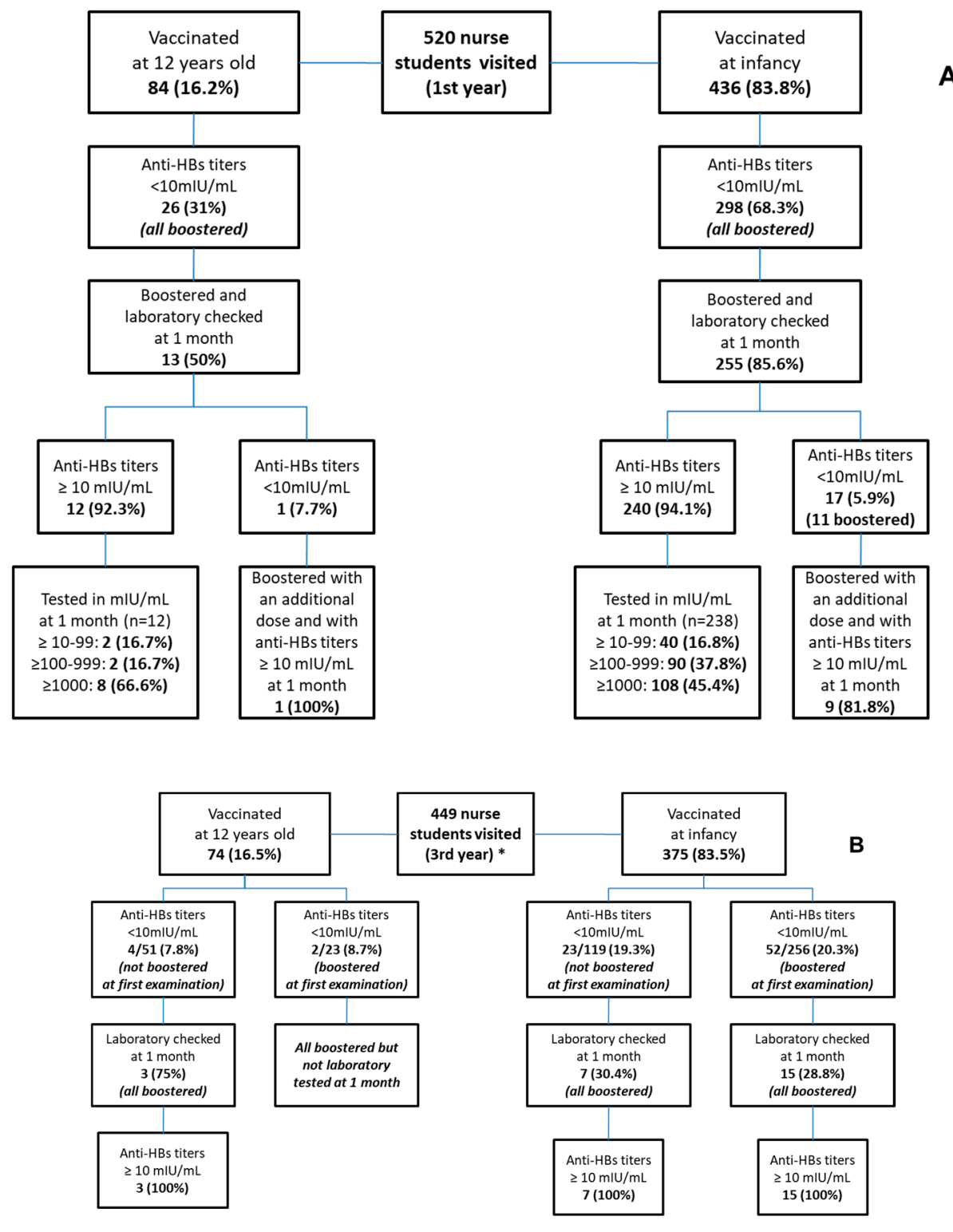

Figure 1. (A) and (B). Students enrolled at occupational examinations conducted during the 1st $(n=520)$ and 3rd year $(n=449)$ of the nursing study course.

All students with a titer $\leq 10 \mathrm{mIU} / \mathrm{mL}$ at the first visit (298 out of 436 vaccinated during infancy, 26 out of 84 vaccinated during adolescence) were boosted within one month.

After the booster, seroprotection rates were similar in students who were vaccinated during adolescence ( $92 \%$ of which $66.6 \%$ reporting levels of anti-HBsAg $\geq 1000 \mathrm{mUI} / \mathrm{mL}$ ) and in those who were vaccinated during infancy ( $94.1 \%$ of which $45.4 \%$ reporting levels of anti-HBsAg $\geq 1000 \mathrm{mUI} / \mathrm{Ml}$ ). At the third year of the course, a higher percentage of students with anti-HBsAg $<10$ required a booster among those who were vaccinated during infancy compared to those who were vaccinated during adolescence, independently from having received a booster dose at the first year of the study course ( $20 \%$ versus $8.1 \%)$. 


\subsection{Serological Tests}

Serological analyses were performed with commercial chemiluminescence assays (VITROS anti-HBs assay on the Vitros ECI Immunodiagnostic system, Ortho-Clinical Diagnostics, United Kingdom).

In particular, the antibody to the hepatitis B surface antigen (anti-HBs) levels were expressed as $\mathrm{mIU} / \mathrm{mL}$. A dynamic range of quantification is $10-1000 \mathrm{mIU} / \mathrm{mL}$. A level of anti-HBs above $10 \mathrm{mIU} / \mathrm{mL}$ was considered as protective against $\mathrm{HBV}$ infection.

\subsection{Statistical Analysis}

Absolute and relative frequencies were calculated for the categorical (qualitative) variables and normally distributed quantitative variables were summarized by their means (standard deviations). The differences in the categorical variables were analyzed using chi-squared tests (or Fisher's exact test when appropriate) and the Student t-test for the means.

All the variables that were found to have an association with protective Hepatitis B surface antibody titers $(\geq 10 \mathrm{mIU} / \mathrm{mL})$ at the first visit were included in a multivariate backward stepwise logistic regression model. Crude and adjusted OR with 95\% confidence intervals (CIs) were also calculated in the logistic regression model. All information were entered into a database created with Excel 10.0. All data were analyzed using the statistical software package Stata/MP 12.1 (StataCorp LP, College Station, USA).

\section{Results}

The main characteristics of the subjects that were included in the study are shown in Table 1. A total of 520 students $(n=436$ vaccinated during infancy, $83.8 \% ; n=84$ vaccinated during adolescence, $16.2 \%$ ) underwent an occupational examination during the first year of their degree course. The mean age was 20.5 years $(\mathrm{SD} \pm 1.6)$ for students who were vaccinated during infancy and 29.3 years $(\mathrm{SD} \pm 4.9)$ for students who were vaccinated during adolescence ( $p$-value $<0.001)$. A higher percentage of female students among those that were vaccinated during infancy $(66.3 \%$ versus $59.5 \%$ among students vaccinated during adolescence) was observed.

Table 1. General characteristics of the nursing students enrolled during the 1st year of the study course $(n=520)$.

\begin{tabular}{cccc}
\hline $\boldsymbol{n}=\mathbf{5 2 0}$ & $\begin{array}{c}\text { Vaccination during } \\
\text { Infancy } \\
(\boldsymbol{n}=\mathbf{4 3 6})\end{array}$ & $\begin{array}{c}\text { Vaccination during } \\
\text { Adolescence } \\
(\boldsymbol{n}=\mathbf{8 4})\end{array}$ & $\boldsymbol{p}$-Value \\
\hline $\begin{array}{c}\text { Mean age } \pm \text { DS } \\
\text { Gender, } n(\%)\end{array}$ & $20.5 \pm 1.6$ & $29.3 \pm 4.9$ & $<0.001$ \\
Male & $147(33.7)$ & $34(40.5)$ & 0.14 \\
Female & $289(66.3)$ & $50(59.5)$ & $<0.001$ \\
$\begin{array}{c}\text { Years from vaccination, } \\
\text { mean } \pm \text { DS }\end{array}$ & $20.5 \pm 1.6$ & $17.3 \pm 4.9$ & \\
$\begin{array}{c}\text { Anti-HBs titers, } n(\%) \\
<10 \mathrm{mIU} / \mathrm{mL}\end{array}$ & $298(68.3)$ & $26(31.0)$ & $<0.001$ \\
$\geq 10 \mathrm{mIU} / \mathrm{mL}$ & $138(31.7)$ & $58(69.0)$ &
\end{tabular}

The mean of years passed from the primary cycle of HBV vaccination was significantly higher among students who were vaccinated during infancy than among students vaccinated during adolescence $(20.5 \pm 1.6$ versus $17.3 \pm 4.9 ; p$-value $<0.001)$. Fifty-eight $(69 \%)$ students who were vaccinated during adolescence showed Hepatitis B surface antibody titers $\geq 10 \mathrm{mIU} / \mathrm{mL}$, while the prevalence of subjects with anti-HBs titers $\geq 10 \mathrm{mIU} / \mathrm{mL}$ among students vaccinated during infancy was $31.7 \%$ ( $p$-value $<0.001)$. 
In Table 2, the results of the univariate and multivariate analysis of factors associated with protective levels of anti-HBs at first examination are reported. After adjustment for confounding variables, receiving $\mathrm{HBV}$ vaccination during adolescence was significantly associated with increased possibilities of having Hepatitis B surface antibody titers $\geq 10 \mathrm{mIU} / \mathrm{mL}$ (adj-OR $=4.21,95 \% \mathrm{CI}=2.43-7.30$ ). In the multivariable analysis, years passed since the first HBV vaccination schedule and gender were not significantly associated with higher anti-HBsAg values.

Table 2. Factors associated with protective Hepatitis B surface antibody titers ( $\geq 10 \mathrm{mIU} / \mathrm{mL})$ at the first year occupational examination among nursing students $(n=520)$.

\begin{tabular}{|c|c|c|c|c|c|c|}
\hline & Crude OR & $95 \%$ CI & $p$-Value & AdjOR & $95 \% \mathrm{CI}$ & $p$-Value \\
\hline Years since HBV vaccination & 0.87 & $0.81-0.93$ & $<0.01$ & 0.96 & $0.89-1.03$ & 0.25 \\
\hline \multicolumn{7}{|l|}{ Gender } \\
\hline Male & ref & & \multirow{2}{*}{0.60} & ref & & \multirow{2}{*}{0.80} \\
\hline Female & 0.90 & $0.62-1.31$ & & 0.95 & $0.64-1.40$ & \\
\hline \multicolumn{7}{|l|}{ HBV vaccination timing } \\
\hline vaccinated during infancy & ref & & \multirow{2}{*}{$<0.001$} & ref & & \multirow{2}{*}{$<0.001$} \\
\hline vaccinated during adolescence & 4.81 & $2.90-7.97$ & & 4.21 & $2.43-7.30$ & \\
\hline
\end{tabular}

In Table 3, the serological characteristics of the student cohort that was reassessed for HBV at control examination conducted during the third year of the degree $(n=449)$ were reported. Subjects vaccinated during infancy $(n=375)$ showed a higher percentage of anti-HBsAg $<10 \mathrm{mUI} / \mathrm{mL}(20 \%$ versus $8.1 \%$ among those vaccinated during adolescence; $p<0.01)$. A higher percentage of students with anti-HBsAg $<10 \mathrm{mUI} / \mathrm{mL}$ was observed, although this was not significant when also considering students boosted (20.3\% versus $8.7 \%$ among those vaccinated during adolescence) and not boosted after the first visit (19.3\% versus $7.9 \%$ among those vaccinated during adolescence).

Table 3. Anti-HBs titers observed among nursing students during their occupational examination during the third year of their study course $(n=449)$.

\begin{tabular}{|c|c|c|c|}
\hline & $\begin{array}{l}\text { Vaccination during } \\
\text { Infancy } \\
n(\%)\end{array}$ & $\begin{array}{c}\text { Vaccination during } \\
\text { Adolescence } \\
n(\%)\end{array}$ & $p$-Value \\
\hline \multicolumn{4}{|c|}{ Anti-HBs titers at the control visit (third year), $(n=449)$} \\
\hline$<10 \mathrm{mIU} / \mathrm{mL}$ & $75(20.0)$ & $6(8.1)$ & \multirow{2}{*}{$<0.01$} \\
\hline$\geq 10 \mathrm{mIU} / \mathrm{mL}$ & $300(80.0)$ & $68(91.9)$ & \\
\hline \multicolumn{4}{|c|}{ Anti-HBs titers at the control visit (third year) among students not boosted after their first visit, $(n=170)$} \\
\hline$<10 \mathrm{mIU} / \mathrm{mL}$ & $23(19.3)$ & $4(7.9)$ & \multirow{2}{*}{0.06} \\
\hline$\geq 10 \mathrm{mIU} / \mathrm{mL}$ & $96(80.7)$ & $47(92.1)$ & \\
\hline \multicolumn{4}{|c|}{ Anti-HBs titers at the control visit (third year) among students boosted after their first visit, $(n=279)$} \\
\hline$<10 \mathrm{mIU} / \mathrm{mL}$ & $52(20.3)$ & $2(8.7)$ & \multirow{2}{*}{0.18} \\
\hline$\geq 10 \mathrm{mIU} / \mathrm{mL}$ & 204 (79.7) & $21(91.3)$ & \\
\hline
\end{tabular}

\section{Discussion}

Undoubtedly, during their practical training, students attending a medical degree course, such as nursing students, can be professionally exposed to the risk of contracting infectious diseases as well as HBV infection [2,18].

Several studies conducted on similar populations showed that subjects vaccinated at birth or during adolescence maintain a protective antibody titer in the following 10 years in most cases, 
while the percentage is reduced 20 years after the primary vaccination schedule, especially if the vaccination was performed during the neonatal age $[9,19,20]$.

In particular, two recently published Italian studies found a lower proportion of subjects with anti-HBs titre $<10 \mathrm{mIU} / \mathrm{mL}$ than those observed in our cohort $37.7 \%$ in Palermo versus $30.8 \%$ in Florence and $12 \%$ in Rome) [21,22]. These findings are quite different when also considering the time of vaccination and a higher proportion of subjects with non-protective antibody titers was found in our cohort, both considering subjects vaccinated during infancy $(68.3 \%$ in Palermo versus $51 \%$ in Florence and $22.8 \%$ in Rome) and subjects vaccinated during adolescence (31\% in Palermo versus $12 \%$ in Florence and 10\% in Rome) [21,22]. Unfortunately, mean age and intervals between primary vaccination and antiHBs titers check seem to be quite similar between the different studies. To date, the reasons for such differences are not clear to us and further investigations are required. On the other hand, in all three settings, vaccination during adolescence elicited higher anti-HBs titres compared to vaccinations performed during infancy.

The different immunological response that was observed among young healthcare professionals who were vaccinated during infancy and during adolescence could be, at least in part, attributable not only to the maturity of the immune response system at the time of the first vaccination cycle completion, but also to the lower dosage contained in the neonatal anti-HBV vaccines compared to some vaccines administered during adolescence [23].

This study seems to confirm these findings and shows that after adjusting for years passed since the first vaccination, statistically significantly higher anti-HBsAg values were observed among nursing students vaccinated during adolescence.

Moreover, the rate of anti-HbsAg antibody titer $<10 \mathrm{mIU} / \mathrm{mL}$ was surprisingly higher in the cohort of subjects who were vaccinated during infancy that were boosted two years before $(n=52,69.3 \%$ of subjects with anti-HBsAg $<10 \mathrm{mIU} / \mathrm{mL}$ at the third year of the study course), also suggesting that after anti-HBV booster, subjects that are vaccinated during infancy could rapidly decrease their anti-HBsAg levels below $10 \mathrm{mIU} / \mathrm{mL}$.

In Italy, several studies have demonstrated a low endemic level of HBV (prevalence of HBsAg in the general population $<2 \%$ ), with an incidence of about 1 case per 100,000 individuals and this result is indubitably attributable to the universal vaccination strategies adopted in $1991[8,24]$.

The epidemiology of HBV in developed countries suggests that healthcare workers, and in particular, healthcare students, could have a low risk of contracting the disease, despite not being negligible [25]. For these reasons, to date in Italy, for healthcare professionals as well as for medical residents, students, and trainees, the vaccination against $\mathrm{HBV}$ is actively strongly recommended and is free of charge, however there are no mandatory anti-HBV vaccination booster policies [10].

The results of the present study confirm that among the boosted subjects, different responses could be observed and, generally, there was a significant correlation between higher levels of anti-HBs after booster and protective anti-HBs titers after two years.

This correlation was also observed, even though it was not statistically significantly, between high baseline levels of anti-HBs and anti-HBs titers $\geq 10 \mathrm{mIU} / \mathrm{mL}$ after two years. These two correlations were independent from the primary administration of the HBV vaccination schedule.

Future studies that analyze the modification of anti-HBs levels over time for not boosted and boosted healthcare workers could take these results into consideration.

Moreover, the data obtained in this study could also help to further clarify the effect of the HBV vaccination booster, demonstrating a rapid antibody response from the primary vaccination cycle several years later in subjects that were originally responders [25].

Even though to date, a large majority of Italian healthcare students, trainees, medical residents, and workers $\leq 39$ years old have been vaccinated according to the national immunization schedule, a standardized screening for HBV, provided by Occupational Medicine services, it is fundamental not only to identify subjects with low levels of anti-HBsAg or non-responders after primary vaccination 
cycle, but also for detecting HCWs older than 40-years-old that have not been vaccinated at birth or at 12 years of age.

In this sense, it should be noted that the Italian Legislation recommends the administration of an HBV booster dose for health care workers with anti-HbsAg antibody titer $<10 \mathrm{mIU} / \mathrm{mL}$ [26].

At first, this recommendation seems to conflict with the World Health Organization position paper on Hepatitis B vaccines, suggesting that subjects with an anti-HBs titer $<10 \mathrm{mIU} / \mathrm{mL}$ still retain immune memory and therefore, a booster dose in the routine immunization schedule is not recommended [27].

Our results confirm that once the presence of immunological memory in these subjects is demonstrated, regardless of the decline observed in a limited group of boosted subjects two years before, it would no longer make sense to retest them periodically for anti-HBsAg in health surveillance protocols [28,29].

Moreover, despite declining serum levels of anti-HBsAg, international evidences show that vaccine-induced immunity continues to prevent clinical disease or detectable HBV infection [30].

Unfortunately, this study could have some limitations. A first possible limitation is due to the relatively small sample size, which could have reduced the relevance of the statistical tests in finding statistically significant differences. A second limitation is the lack of data about the first vaccination schedule (mostly type of vaccine, etc.). Moreover, the presence of some students lost to laboratory follow-up could have introduced a potential selection bias.

Despite the presence of these possible limitations, our findings confirm the expected reduction of anti-HBsAg two decades after the HBV primary vaccination schedule, which was more evident in subjects who were vaccinated during infancy due to a probable immaturity of the immune system at that time or to the use of a vaccine with lower antigenic content [31].

\section{Conclusions}

This study confirms that $\mathrm{HBV}$ vaccination during adolescence might determine a higher long-term persistence of anti-HBsAg titers $\geq 10 \mathrm{mIU} / \mathrm{mL}$ and that $\mathrm{HBV}$ booster could increase levels of anti-HBsAg over a relatively short period, especially in subjects who were vaccinated during infancy.

Moreover, more than two-thirds of the subjects vaccinated during infancy showed levels of anti-HBsAg $<10 \mathrm{mIU} / \mathrm{mL}$ at the first visit and after having developed a valid immunity one month after the booster dose, among $20 \%$ of students boosted two years earlier, anti-HBsAg levels were again $<10 \mathrm{mIU} / \mathrm{mL}$ at the control visit (third year).

It is highly likely that when encountering the natural $\mathrm{HBV}$ virus, subjects who were vaccinated or boosted that showed anti-HBsAg levels $<10 \mathrm{mIU} / \mathrm{mL}$ at the first or third visit will produce a valid antibody reaction that is capable of antagonizing the infection.

These findings support the recommendation by the regulatory Health Agencies to screen and administer a booster dose for first time individuals belonging to high-risk groups, such as professionals employed in health-care services, and in future, could represent a suggestion for the management of health-care workers vaccinated against HBV during infancy or adolescence according to their anti-HBs immunization status [32].

In future, it could be useful to increase the number of subjects enrolled in the study to confirm and increase the generalizability of our results, identifying other variables that could play a further role in determining the seroconversion rate and perdurance of antibody levels.

Author Contributions: Conceptualization: C.C. and M.G.V.; methodology, C.C., M.G.V., and E.A.; validation, C.C., M.G.V., and E.A.; formal analysis, C.C. and E.A.; investigation, M.G.V.; data curation, C.C.; writing-original draft preparation, C.C. and M.G.V.; writing-review and editing, E.A. and F.V.; supervision, M.G.V. and F.V. All authors have read and agreed to the published version of the manuscript.

Funding: This research received no external funding.

Conflicts of Interest: The authors declare no conflict of interest. 


\section{References}

1. World Health Organization (WHO). Occupational Health, Health Workers and Health Worker Occupational Health. Available online: http://www.who.int/occupa-tional_health/topics/hcworkers/en/ (accessed on 6 November 2019).

2. Lewis, J.D.; Enfield, K.B.; Sifri, C.D. Hepatitis B in healthcare workers: Transmission events and guidance for management. World J. Hepatol. 2015, 7, 488-497. [CrossRef] [PubMed]

3. Repubblica Italiana-Decreto Legislativo 9 Aprile 2008, n. 81. Attuazione Dell'articolo 1 Della Legge 3 Agosto 2007, n. 123 in Materia Di Tutela Della Salute e Della Sicurezza Nei Luoghi Di Lavoro. Available online: https://www.gazzettaufficiale.it/eli/id/2008/04/30/008G0104/sg (accessed on 6 November 2019).

4. Advisory Committee on Immunization Practices; Centers for Disease Control and Prevention (CDC). Immunization of Healthcare Personnel: Recommendations of the Advisory Committee on Immunization Practices (ACIP). Mmwr Recomm. Rep. 2011, 60, 1-45.

5. Jack, A.D.; Hall, A.J.; Maine, N.; Mendy, M.; Whittle, H.C. What level of hepatitis B antibody is protective? J. Infect. Dis. 1999, 179, 489-492. [CrossRef] [PubMed]

6. Jan, C.F.; Huang, K.C.; Chien, Y.C.; Greydanus, D.E.; Davies, H.D.; Chiu, T.Y.; Huang, L.M.; Chen, C.J.; Chen, D.S. Determination of immune memory to hepatitis B vaccination through early booster response in college students. Hepatology 2010, 51, 1547-1554. [CrossRef]

7. Hudu, S.A.; Malik, Y.A.; Niazlin, M.T.; Harmal, N.S.; Adnan, A.; Alshrari, A.S.; Sekawi, Z. Antibody and immune memory persistence post infant hepatitis B vaccination. Patient Prefer Adherence 2013, 7, 981-986. [CrossRef]

8. Zanetti, A.R.; Tanzi, E.; Romanò, L.; Grappasonni, I. Vaccination against hepatitis B: theItalian strategy. Vaccine 1993, 11, 521-524. [CrossRef]

9. Romanò, L.; Galli, C.; Tagliacarne, C.; Tosti, M.E.; Velati, C.; Fomiatti, L.; Chironna, M.; Coppola, R.C.; Cuccia, M.; Mangione, R.; et al. Persistence of immunity 18-19 years after vaccination against hepatitis B in 2 cohorts of vaccinees primed as infants or as adolescents in Italy. Hum. Vaccin. Immunother. 2017, 13, 981-985. [CrossRef]

10. Ministero della Salute. Piano Nazionale Prevenzione Vaccinale 2017-2019. Available online: http://www. salute.gov.it/imgs/C_17_pubblicazioni_2571_allegato.pdf (accessed on 6 November 2019).

11. Lohouès-Kouacou, M.-J.; Assi, C.; Nigué, L.; Biékré, A.R.; Ouattara, A.; Koné, S.; Soro, D.; Allah-Kouadio, E.; Okon, J.B.A.; Diakité, M.; et al. Hepatitis B: Cross-sectional study of knowledge and immunization among students at University of Cocody, Ivory Coast. Rev. Epidemiol. Sante Publique. 2013, 61, 494-498. [CrossRef]

12. Verso, M.G.; Cascio, N.L.; Laddeca, E.N.; Amodio, E.; Currieri, M.; Giammanco, G.; Ferraro, D.; De Grazia, S.; Picciotto, D. Predictors of Hepatitis B Surface Antigen Titers two decades after vaccination in a cohort of students and post-graduates of the Medical School at the University of Palermo, Italy. Ann. Agric. Environ. Med. 2017, 24, 303-306. [CrossRef] [PubMed]

13. Spradling, P.R.; Williams, R.E.; Xing, J.; Soyemi, K.; Towers, J. Serologic testing for protection against hepatitis $\mathrm{B}$ virus infection among students at a health sciences university in the United States. Infect. Control Hosp. Epidemiol. 2012, 33, 732-736. [CrossRef]

14. Cárdenas-Perea, M.E.; Gómez-Conde, E.; Santos-López, G.; Pérez-Contreras, I.; Díaz-Orea, M.A.; Gándara-Ramírez, J.L.; López, O.R.C.Y.; Marquez-Dominguez, L.; Sosa-Jurado, F. Hepatitis B surface antibodies in medical students from a public university in Puebla, Mexico. Hum. Vaccin. Immunother. 2016, 12, 1857-1862. [CrossRef] [PubMed]

15. Su, F.H.; Chen, J.D.; Cheng, S.H.; Lin, C.H.; Liu, Y.H.; Chu, F.Y. Seroprevalence of Hepatitis-B infection amongst Taiwanese university students 18 years following the commencement of a national Hepatitis-B vaccination program. J. Med. Virol. 2007, 79, 138-143. [CrossRef] [PubMed]

16. Sernia, S.; Ortis, M.; Antoniozzi, T.; Maffongelli, E.; La Torre, G. Levels of anti-HBs antibody in HBV-vaccinated students enrolled in the faculty of medicine, dentistry and health professions of a large Italian University. BioMed Res. Int. 2015, 2015, 712020. [CrossRef] [PubMed]

17. Italian Medicines Agency. Linee Guida Per La Classificazione e Conduzione Degli Studi Osservazionali Sui Farmaci. Gazzetta Ufficiale 2008, 76. 31/03/ 2008. Available online: http://www.agenziafarmaco.gov.it/ allegati/det_20marzo2008.pdf (accessed on 6 November 2019). 
18. La Torre, G.; Scalingi, S.; Garruto, V.; Siclari, M.; Chiarini, M.; Mannocci, A. Knowledge, Attitude and Behaviours towards Recommended Vaccinations among Healthcare Workers. Healthcare 2017, 5, 13. [CrossRef] [PubMed]

19. Bruce, M.G.; Bruden, D.; Hurlburt, D.; Zanis, C.; Thompson, G.; Rea, L.; Toomey, M.; Townshend-Bulson, L.; Rudolph, K.; Bulkow, L.; et al. Antibody Levels and Protection After Hepatitis B Vaccine: Results of a 30-Year Follow-up Study and Response to a Booster Dose. J. Infect. Dis. 2016, 214, 16-22. [CrossRef] [PubMed]

20. Bialek, S.R.; Bower, W.A.; Novak, R.; Helgenberger, L.; Auerbach, S.B.; Williams, I.T.; Bell, B.P. Persistence of protection against hepatitis $B$ virus infection among adolescents vaccinated with recombinant hepatitis B vaccine beginning at birth: A 15-year follow-up study. Pediatr. Infect. Dis. J. 2008, 27, 881-885. [CrossRef] [PubMed]

21. Coppeta, L.; Pompei, A.; Balbi, O.; Zordo, L.M.; Mormone, F.; Policardo, S.; Lieto, P.; Pietroiusti, A.; Magrini, A.; De Zordo, L.M. Persistence of Immunity for Hepatitis B Virus among Heathcare Workers and Italian Medical Students 20 Years after Vaccination. Int. J. Environ. Res. Public Health 2019, 16, 1515. [CrossRef] [PubMed]

22. Bini, C.; Grazzini, M.; Chellini, M.; Mucci, N.; Arcangeli, G.; Tiscione, E.; Bonanni, P. Is hepatitis B vaccination performed at infant and adolescent age able to provide long-term immunological memory? An observational study on healthcare students and workers in Florence, Italy. Hum. Vaccin. Immunother. 2018, 14, 450-455. [CrossRef]

23. Osiowy, C. From infancy and beyon ensuring a lifetime of hepatitis B virus (HBV) vaccine-induced immunity. Hum. Vaccin. Immunother. 2018, 14, 2093-2097. [CrossRef]

24. Romanò, L.; Paladini, S.; Tagliacarne, C.; Zappa, A.; Zanetti, A.R. The changing face of the epidemiology of type A, B, and D viral hepatitis in Italy, following the implementation of vaccination. Vaccine 2009, 26, 3439-3442. [CrossRef]

25. Lamberti, M.; De Rosa, A.; Garzillo, E.M.; Corvino, A.R.; Sannolo, N.; De Pascalis, S.; Di Fiore, E.; Westermann, C.; Arnese, A.; Gabriella, D.G.; et al. Vaccination against hepatitis b virus: Are Italian medical students sufficiently protected after the public vaccination programme? J. Occup. Med. Toxicol. 2015, 10, 41. [CrossRef] [PubMed]

26. Avdicova, M.; Crasta, P.D.; Hardt, K.; Kovac, M. Lasting immune memory against hepatitis B following challenge 10-11 years after primary vaccination with either three doses of hexavalent DTPa-HBV-IPV/Hib or monovalent hepatitis B vaccine at 3, 5 and 11-12 months of age. Vaccine 2015, 33, 2727-2733. [CrossRef] [PubMed]

27. Publication, W.H.O. Hepatitis B vaccines: WHO position paper-recommendations. Vaccine 2010, 28, 589-590. [CrossRef]

28. Dini, G.; Toletone, A.; Barberis, I.; DeBarbieri, N.; Massa, E.; Paganino, C.; Bersi, F.; Montecucco, A.; Alicino, C.; Durando, P. Persistence of protective anti-HBs antibody levels and anamnestic response to HBV booster vaccination: A cross-sectional study among healthcare students 20 years following the universal immunization campaign in Italy. Hum. Vaccin. Immunother. 2017, 13, 440-444. [CrossRef] [PubMed]

29. Floreani, A.; Baldo, V.; Cristofoletti, M.; Renzulli, G.; Valeri, A.; Zanetti, C.; Trivello, R. Long-term persistence of anti-HBs after vaccination against HBV: An 18 year experience in health care workers. Vaccine 2004, 22, 607-610. [CrossRef] [PubMed]

30. Chiara, F.; Bartolucci, G.B.; Cattai, M.; Piazza, A.; Nicolli, A.; Buja, A.; Trevisan, A. Hepatitis B vaccination of adolescents: Significance of non-protective antibodies. Vaccine 2013, 32, 62-68. [CrossRef] [PubMed]

31. Rosenberg, C.A.; Bovin, N.V.; Bram, L.V.; Flyvbjerg, E.; Erlandsen, M.; Vorup-Jensen, T.; Petersen, E. Age is an important determinant in humoral and $\mathrm{T}$ cell responses to immunization with hepatitis $\mathrm{B}$ surface antigen. Hum. Vaccin. Immunother. 2013, 9, 1466-1476. [CrossRef] [PubMed]

32. Schillie, S.; Murphy, T.V.; Sawyer, M.; Ly, K.; Hughes, E.; Jiles, R.; De Perio, M.A.; Reilly, M.; Byrd, K.; Ward, J.W. CDC guidance for evaluating health-care personnel for hepatitis B virus protection and for administering postexposure management. Mmwr. Recomm. Rep. 2013, 62, 62.

(C) 2019 by the authors. Licensee MDPI, Basel, Switzerland. This article is an open access article distributed under the terms and conditions of the Creative Commons Attribution (CC BY) license (http://creativecommons.org/licenses/by/4.0/). 